\title{
THE MARKETABILITY DISCOUNT IN SPANISH VALUATION MULTIPLES: INVESTORS' PERCEPTION IN LISTED COMPANIES VERSUS PRIVATE TRANSACTIONS
}

\author{
Ángel RODRÍGUEZ LÓPEZ ${ }^{(\mathbb{} *}$, Gracia RUBIO MARTÍN \\ Department of Accounting and Finance, Complutense University of Madrid, Madrid, Spain
}

Received 18 April 2018; accepted 24 January 2019

\begin{abstract}
The aim of this paper is to assess the fair marketability discount $(M D)$ in the Spanish market for valuation multiples comparing public versus private transactions. The study finds that to obtain $M D$ it is necessary previously to control by a battery of factors that affects ratios' prices such as industry, firm size, profitability, risk, year and also other characteristics about the buyer. The interactions of $M D$ with each variable showed different investors' perceptions about non marketability enterprises explaining $M D$. The valuation methodology applied in the research was a cross section of 824 public and private acquisitions in the Spanish market from the period 2006-2017. This work represents important evidence, in a more integrated vision than previous literature, for analysts and regulators stressing the necessity to apply $M D$ in Spanish valuation processes based in listed multiples.
\end{abstract}

Keywords: valuation multiples, ratios analysis, marketability discount, illiquidity discount, market ratio valuation, EBITDA ratio.

JEL Classification: G10, G120.

\section{Introduction}

The use of market valuation multiples has become very important (Covrig \& McConaughy, 2015; Dong, Jiao, \& Sun, 2017; Ferraro, 2017; Serra \& Fávero, 2017; Gupta, 2018). Its use is recommended by both international accounting standard (IFRS 13) and by the main international asset valuation guidelines (EVCA). A valuation multiple is a ratio, normally the market value of a firm's assets divided by an economic magnitude of it. The objective of the multiples valuation is to assess a company by creating a benchmark, usually based on industry information.

Academic literature has evaluated in listed companies the accuracy of the valuation multiples depending on the economic characteristics in the peer group selection. They concluded that a specific industry could not provide enough criteria, and other control factors like size, profitability and risk have to be added (Alford, 1992; Kim \& Ritter, 1999; Bhojraj \& Lee, 2002;

*Corresponding author. E-mails: arlopez@ccee.ucm.es, anrod20012000@yahoo.es 
E. Lie \& H. J. Lie, 2002; Liu, Nissim, \& Thomas, 2002, 2007; López, Antón, \& Cerviño, 2011; Young \& Zeng, 2015; Celli, 2017; Rubio, 2019).

Moreover, the implementation of a market model comparing a private company to industry listed firms in a valuation process adds complexity since it also requires the use of an appropriated illiquidity discount (Grbenic, 2017). The study of the illiquidity discount in the price of unlisted versus quoted companies in the American market was recurrent in financial literature at the end of the past century (Hertzel \& Smith, 1983; Wruck, 1989; Silber, 1991; Emory, 1997), as well in the first decade of the current one (Koeplin, Sarin, \& Shapiro, 2000; Bajaj, Denis, Ferris, \& Sarin, 2001; Officer, 2007; De Franco, Gavious, Jin, \& Richardson, 2008; Elnathan, Gavious, \& Hauser, 2010). However, we observed in these authors a lack of consensus in the variables which define the peer group, as well as the assessment of the illiquidity discount.

The objectives of this paper are to assess the marketability discount in the Spanish market for the EBITDA and SALES ratios and to explain the behaviour of it. The article integrates different points of view and theories across economic enterprises characteristics and incorporates different aspects from the buyer and his negotiation capacity in the final price. To carry out this task the method applied in this research was a cross section from the years 2006-2017. The results provide a logic media discount for each ratio, but also that the discount varies largely depending on the characteristics of the companies and the buyers.

This paper is organized as follows: after the Introduction, in the second section, the work reviews the previous literature on pricing by multiples and illiquidity discount theory and proposes the hypothesis to contrast. In the third section, the research discusses a valuation model for each ratio using cross section methodology. In the fourth section, the study deals with data description and presents the results obtained from the estimation of the proposed model. The article ends with the discussion and final conclusions.

\section{Theoretical framework and hypothesis}

Multiples methodology is very intuitive because it does not require detailed multi-year forecasting of free cash flows or projected residual incomes, as is the case of discounted cash flows (DCF approach). Instead, the value of the firm is associated with a peer group of firms considered to be comparable. A simple analysis of the stock prices of the firms in the peer group leads to a certain ratio which will be used as a multiplier of the target firm's value driver. This is especially useful to determine the price in a private transaction. A usual approach is to value the enterprise as if it were marketable, based on market-ratios transactions, then a marketability discount is necessary to calculate and to apply it. Bajaj et al. (2001) and also Pratt (2009) define Marketability as the degree to which an asset can be converted into cash quickly with almost no transaction costs.

\subsection{Illiquidity framework}

However, since a marketability discount $(M D)$ seems necessary, in previous literature, different models obtained results that differed substantially depending on the form in selecting the peer group and the reason for explaining the $M D$. Table 1 summarizes the different theories. 
Table 1. Literature review referred to marketability/illiquidity discount

\begin{tabular}{|c|c|c|c|c|c|c|c|}
\hline $\begin{array}{l}\text { Period } \\
\& \mathrm{Au}- \\
\text { thor }\end{array}$ & $\begin{array}{l}\text { No } \\
\text { obs }\end{array}$ & $\begin{array}{c}\text { Coun- } \\
\text { try }\end{array}$ & $\begin{array}{l}\text { Study's } \\
\text { objective }\end{array}$ & Methodology & $\begin{array}{c}\text { Indepen- } \\
\text { dent } \\
\text { Variables }\end{array}$ & $\begin{array}{c}\text { Dependent } \\
\text { Variables/ } \\
\text { M.ratios }\end{array}$ & $\begin{array}{l}\text { Results/ } \\
\text { Medium } \\
\text { discount }\end{array}$ \\
\hline 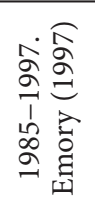 & 310 & USA & $\begin{array}{l}\text { To calculate } \\
\text { the illiquid- } \\
\text { ity discount } \\
\text { in IPO } \\
\text { transactions }\end{array}$ & $\begin{array}{l}\text { Matching itself. } \\
\text { Differences } \\
\text { between prices } \\
\text { from pre-IPO } \\
\text { and post-IPO } \\
\text { moment }\end{array}$ & - & - & $\begin{array}{l}\text { The discount } \\
\text { changes over } \\
\text { the years, } \\
\text { from } 60 \% \text { to } \\
43 \%\end{array}$ \\
\hline 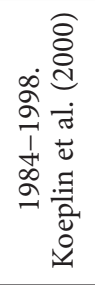 & 84 & USA & $\begin{array}{l}\text { To calculate } \\
\text { the illiquid- } \\
\text { ity discount } \\
\text { comparing } \\
\text { Public v } \\
\text { Private en- } \\
\text { terprises }\end{array}$ & $\begin{array}{l}\text { Matching one } \\
\text { to one based on } \\
\text { year, industry, } \\
\text { size and coun- } \\
\text { try; equation } \\
\text { (1). After, cross } \\
\text { section model }\end{array}$ & $\begin{array}{l}\text { Indus- } \\
\text { try, Size, } \\
\text { Growth, } \\
\text { Dummy for } \\
\text { public or } \\
\text { private }\end{array}$ & $\begin{array}{l}\text { EV/EBITDA; } \\
\text { EV/EBIT; } \\
\text { EV/Book } \\
\text { value; } \\
\text { EV/Sales }\end{array}$ & $\begin{array}{l}\text { They found } \\
\text { an average } \\
\text { discount of } \\
28 \% \text { for EV/ } \\
\text { EBITDA, but } \\
\text { a minimum } \\
\text { of }-2.28 \% \\
\text { for EV/Sales }\end{array}$ \\
\hline 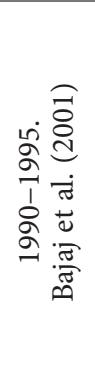 & 88 & USA & $\begin{array}{l}\text { To delimit } \\
\text { the illiquid- } \\
\text { ity discount } \\
\text { from restric- } \\
\text { ted shares } \\
\text { in IPO } \\
\text { transactions } \\
\text { throughout a } \\
\text { cross section } \\
\text { model }\end{array}$ & $\begin{array}{l}\text { Matching itself } \\
\text { to determine } \\
\text { the illiquid- } \\
\text { ity discount } \\
\text { between public } \\
\text { and private } \\
\text { prices. After, } \\
\text { cross section } \\
\text { model to ex- } \\
\text { plain the illiqui- } \\
\text { dity discount }\end{array}$ & $\begin{array}{l}\text { Z-Score, } \\
\text { Volatility } \\
\text { of Returns, } \\
\text { Dummy for } \\
\text { restricted } \\
\text { enterprises }\end{array}$ & $\begin{array}{l}\text { Illiquid- } \\
\text { ity discount } \\
\text { from pre- } \\
\text { IPO and } \\
\text { post-IPO } \\
\text { prices }\end{array}$ & $\begin{array}{l}\text { They found } \\
\text { a discount } \\
\text { from } 2 \% \text { to } \\
43 \% \text { depend- } \\
\text { ing on the } \\
\text { economic } \\
\text { factor of } \\
\text { enterprises. } \\
\text { The medium } \\
\text { discount is } \\
14.09 \%\end{array}$ \\
\hline 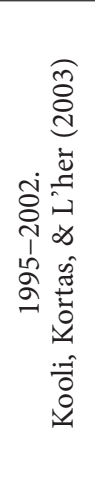 & 331 & USA & $\begin{array}{l}\text { Regarding } \\
\text { the illiquid- } \\
\text { ity discount } \\
\text { comparing } \\
\text { a portfolio } \\
\text { of Public v } \\
\text { one private } \\
\text { enterprise. } \\
\text { After this to } \\
\text { find the fair } \\
\text { illiquidity } \\
\text { discount for } \\
\text { restricted } \\
\text { enterprises }\end{array}$ & $\begin{array}{l}\text { Matching one } \\
\text { private enter- } \\
\text { prise-portfolio } \\
\text { of public enter- } \\
\text { prises based on } \\
\text { year, industry } \\
\text { and size, to de- } \\
\text { termine the illi- } \\
\text { quidity discount } \\
\text { with equation } \\
\text { (1). After, cross } \\
\text { section model }\end{array}$ & $\begin{array}{l}\text { Industry, } \\
\text { and the dif- } \\
\text { ferences be- } \\
\text { tween Size } \\
\text { and Growth } \\
\text { respect Size } \\
\text { and Growth } \\
\text { medium } \\
\text { values for } \\
\text { private en- } \\
\text { terprises }\end{array}$ & $\begin{array}{l}\text { Illiquid- } \\
\text { ity discount } \\
\text { from private } \\
\text { versus public } \\
\text { based on } \\
\text { Price/Sales; } \\
\text { Price/Earn- } \\
\text { ing; Price/ } \\
\text { Cash-Flow }\end{array}$ & $\begin{array}{l}\text { The medium } \\
\text { discount is } \\
24 \% \text { but the } \\
\text { discount } \\
\text { tend for size } \\
\text { and growth } \\
\text { in enter- } \\
\text { prises }\end{array}$ \\
\hline 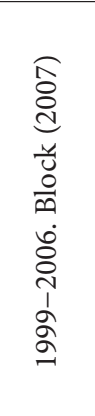 & 91 & USA & $\begin{array}{l}\text { To calculate } \\
\text { the illiquid- } \\
\text { ity discount } \\
\text { comparing } \\
\text { one Public } \\
\text { enterprise } \\
\text { v/ a Private } \\
\text { enterprise } \\
\text { breaking } \\
\text { down the } \\
\text { discount by } \\
\text { industries }\end{array}$ & $\begin{array}{l}\text { Matching one- } \\
\text { one based on } \\
\text { year, industry, } \\
\text { size and coun- } \\
\text { try, increasing } \\
\text { the number } \\
\text { of groups to } 8 \\
\text { including finan- } \\
\text { cial institutions; } \\
\text { Equation (1) }\end{array}$ & & $\begin{array}{l}\text { Price/Earn- } \\
\text { ings; EV/ } \\
\text { Earnings; } \\
\text { EV/Book } \\
\text { value; EV/ } \\
\text { Revenues }\end{array}$ & $\begin{array}{l}\text { The medium } \\
\text { discount is } \\
20 \% \text { but the } \\
\text { lowest dis- } \\
\text { count is in } \\
\text { financial in- } \\
\text { stitution and } \\
\text { the largest } \\
\text { one is in the } \\
\text { manufactur- } \\
\text { ing sector }\end{array}$ \\
\hline
\end{tabular}


Continued Table 1

\begin{tabular}{|c|c|c|c|c|c|c|c|}
\hline $\begin{array}{l}\text { Period } \\
\& \mathrm{Au}- \\
\text { thor }\end{array}$ & $\begin{array}{l}\text { No } \\
\text { obs }\end{array}$ & $\begin{array}{c}\text { Coun- } \\
\text { try }\end{array}$ & $\begin{array}{c}\text { Study's } \\
\text { objective }\end{array}$ & Methodology & $\begin{array}{l}\text { Indepen- } \\
\text { dent } \\
\text { Variables }\end{array}$ & $\begin{array}{c}\text { Dependent } \\
\text { Variables/ } \\
\text { M.ratios }\end{array}$ & $\begin{array}{l}\text { Results/ } \\
\text { Medium } \\
\text { discount }\end{array}$ \\
\hline 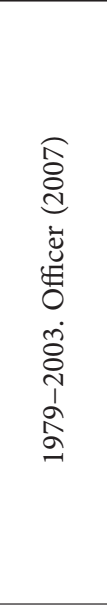 & 364 & USA & $\begin{array}{l}\text { Determine } \\
\text { the discount } \\
\text { Public v } \\
\text { Private and } \\
\text { explain the } \\
\text { behaviour } \\
\text { of it }\end{array}$ & $\begin{array}{l}\text { Matching one- } \\
\text { portfolio based } \\
\text { on industry, } \\
\text { year and size. } \\
\text { Equation (1) }\end{array}$ & \begin{tabular}{|l|} 
Parents' \\
loan spreads \\
and previ- \\
ous abnor- \\
mal prices \\
returns
\end{tabular} & \begin{tabular}{|l|} 
Illiquid- \\
ity discount \\
from private \\
versus public \\
based in (1) \\
in Price/ \\
Earnings; \\
EV/EBITDA; \\
EV/Book \\
value; \\
EV/Sales
\end{tabular} & $\begin{array}{l}\text { Parent firms } \\
\text { sell subsid- } \\
\text { iaries when } \\
\text { their needs } \\
\text { for cash are } \\
\text { important. } \\
\text { The discount } \\
\text { is associated } \\
\text { with parents' } \\
\text { loan spreads } \\
\text { and previous } \\
\text { abnormal } \\
\text { prices re- } \\
\text { turns. The } \\
\text { medium } \\
\text { discount is } \\
20 \%\end{array}$ \\
\hline 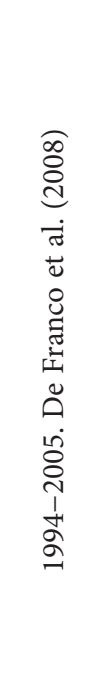 & $\begin{array}{l}664 / \\
2225\end{array}$ & USA & $\begin{array}{l}\text { Determine } \\
\text { the discount } \\
\text { public v } \\
\text { private and } \\
\text { to analyse } \\
\text { differences } \\
\text { of Public vs } \\
\text { Private en- } \\
\text { terprises }\end{array}$ & $\begin{array}{l}\text { They incorpo- } \\
\text { rate a dummy } \\
\text { to detect public } \\
\text { or private based } \\
\text { in a cross sec- } \\
\text { tion model. He } \\
\text { also uses equa- } \\
\text { tion (1) with } \\
\text { medium values } \\
\text { for public } \\
\text { versus private } \\
\text { firms }\end{array}$ & \begin{tabular}{|l|} 
Size and \\
Growth, \\
Sector \\
and Year, \\
(Research \\
and De- \\
velopment \\
and Profit \\
margin for \\
Sales). In a \\
second re- \\
gression he \\
includes ac- \\
crual qual- \\
ity (Big 4 \\
auditor and \\
leverage) \\
and Work- \\
ing Capital
\end{tabular} & $\begin{array}{l}\text { Market } \\
\text { ratios: EV/ } \\
\text { EBITDA; } \\
\text { EV/SALES }\end{array}$ & $\begin{array}{l}\text { Medium } \\
\text { discount: } \\
29 \% \text {, pre- } \\
\text { senting evi- } \\
\text { dences that } \\
\text { valuation } \\
\text { multiples of } \\
\text { public en- } \\
\text { terprises are } \\
\text { increasing } \\
\text { in factors } \\
\text { that proxy } \\
\text { for earnings } \\
\text { quality (e.g., } \\
\text { Big } 4 \text { audi- } \\
\text { tor) as well } \\
\text { as a proxy } \\
\text { for liquidity } \\
\text { (e.g., work- } \\
\text { ing capital) }\end{array}$ \\
\hline 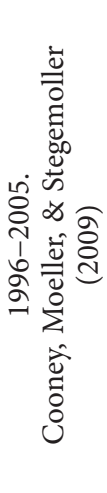 & 68 & USA & $\begin{array}{l}\text { They test } \\
\text { whether } \\
\text { valuation } \\
\text { changes of } \\
\text { the target af- } \\
\text { fect acquirer } \\
\text { announce- } \\
\text { ment returns } \\
\text { in IPOS } \\
\text { withdrawals }\end{array}$ & $\begin{array}{l}\text { Univariate } \\
\text { model }\end{array}$ & $\begin{array}{l}\text { Revision on } \\
\text { the target } \\
\text { valuations } \\
\text { of the IPO } \\
\text { in respect } \\
\text { to the with- } \\
\text { drawn }\end{array}$ & $\begin{array}{l}\text { The three- } \\
\text { day ac- } \\
\text { cumulative } \\
\text { abnormal } \\
\text { return for } \\
\text { the acquirer } \\
\text { around the } \\
\text { acquisition } \\
\text { announce- } \\
\text { ment }\end{array}$ & $\begin{array}{l}\text { This fact } \\
\text { could ex- } \\
\text { plain in } \\
\text { part prior } \\
\text { private un- } \\
\text { dervaluation. } \\
\text { It would } \\
\text { represent } \\
\text { other factor } \\
\text { to separate } \\
\text { from the } \\
\text { illiquidity } \\
\text { discount or } \\
\text { even affect it }\end{array}$ \\
\hline
\end{tabular}


End of Table 1

\begin{tabular}{|c|c|c|c|c|c|c|c|}
\hline $\begin{array}{l}\text { Period } \\
\& \mathrm{Au}^{-} \\
\text {thor }\end{array}$ & $\begin{array}{l}\text { No } \\
\text { obs }\end{array}$ & $\begin{array}{c}\text { Coun- } \\
\text { try }\end{array}$ & $\begin{array}{c}\text { Study's } \\
\text { objective }\end{array}$ & Methodology & $\begin{array}{l}\text { Indepen- } \\
\text { dent } \\
\text { Variables }\end{array}$ & $\begin{array}{l}\text { Dependent } \\
\text { Variables/ } \\
\text { M.ratios }\end{array}$ & $\begin{array}{l}\text { Results/ } \\
\text { Medium } \\
\text { discount }\end{array}$ \\
\hline 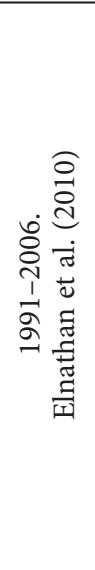 & 147 & Israel & $\begin{array}{l}\text { To compare } \\
\text { public } \mathrm{v} \\
\text { private mar- } \\
\text { ket ratios of } \\
\text { enterprises }\end{array}$ & $\begin{array}{l}\text { Cross section } \\
\text { model }\end{array}$ & \begin{tabular}{|l|} 
Size, Lever- \\
age, Earning \\
Growth, \\
ROE and \\
a dummy \\
variable \\
representing \\
the commis- \\
sioner buyer \\
or seller
\end{tabular} & $\begin{array}{l}\text { EV/Earning; } \\
\text { EV/Book } \\
\text { value }\end{array}$ & $\begin{array}{l}\text { Results } \\
\text { regard the } \\
\text { existence of } \\
\text { a discount in } \\
\text { private firm } \\
\text { valuations } \\
\text { as a conse- } \\
\text { quence of } \\
\text { the experts' } \\
\text { compliance } \\
\text { with the in- } \\
\text { terests of the } \\
\text { commission- } \\
\text { er. Medium } \\
\text { discount of } \\
21 \%\end{array}$ \\
\hline 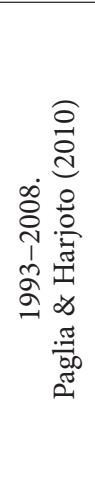 & 431 & USA & $\begin{array}{l}\text { To delimit } \\
\text { and to ex- } \\
\text { plain the } \\
\text { illiquidity } \\
\text { discount in } \\
\text { Public v } \\
\text { Private en- } \\
\text { terprises }\end{array}$ & $\begin{array}{l}\text { Matching one- } \\
\text { one enterprises } \\
\text { based in six } \\
\text { digits Industry } \\
\text { classification, } \\
\text { year, and an- } \\
\text { nual net sales }\end{array}$ & $\begin{array}{l}\text { EBITDA } \\
\text { margin, } \\
\text { dummy } \\
\text { of positive } \\
\text { profits, as- } \\
\text { set or stock } \\
\text { purchase; } \\
\text { status li- } \\
\text { ability cor- } \\
\text { poration; } \\
\text { dummy } \\
\text { for public- } \\
\text { private } \\
\text { companies }\end{array}$ & \begin{tabular}{|l|} 
Illiquidity \\
discount in \\
EV/EBITDA; \\
EV/Sales
\end{tabular} & $\begin{array}{l}\text { The discount } \\
\text { depends } \\
\text { on the in- } \\
\text { dependent } \\
\text { variables } \\
\text { proposed. } \\
\text { The discount } \\
\text { is } 70 \% \text { in } \\
\text { some sec- } \\
\text { tors of the } \\
\text { economy }\end{array}$ \\
\hline
\end{tabular}

In this way, Table 1 presents, following Koeplin et al. (2000) and Bajaj et al. (2001), three different types of studies:

I) Pre-IPO approach. This technique calculates the $M D$ as the difference between the public price at which a stock was issued at the time of the IPO and the private price at which the previous IPO was sold. Emory (1997) found a range for the average $M D$ between 42-48\%, through the period 1985-1997. Garland and Reilly (2004) indicate that Valuation Advisor, LLC (VA) achieved similar conclusions for the period 1999, 2000, 2001 and 2002, while they estimated in the consulting firm Williamette Management Associates a range between 24 to 54\%, depending on the year (1975-2001).

Nevertheless, Koeplin and Saphiro (2000) and Bajaj et al. (2001) found similar criticisms in respect to this methodology: the discounts appear to include the expectation of investors over the public transformation of the company. Secondly, Pre-IPO shares probably are bought by insiders, who provide some sort of service to the firm, such as venture capital or similar, and this fact is implicit in the price. Thirdly, firms with high expectations of growth and profitability carried the IPO ahead. This implies a selection problem because unsuccessful firms are not in the example. 
II) Restricted stock approach, which compares the difference in prices between listed and non marketable shares during a period of time (for example consequence of unregistered private placements). Koeplin and Saphiro (2000) and Bajaj et al. (2001) summarize the results of several previous empirical studies and conclude that the discount range is between 22-35\%. Likewise, Pratt (2009) indicates in his recompilation over this technique an average discount from $13 \%$ to $45 \%$ (the most clustered between $31 \%$ and $36 \%$ ). The first authors criticize this methodology indicating these prices include necessary corporate services given by the companies' insiders in the past or agreements to provide capital in the future. Moreover, the proportion of small unprofitable companies is very large and the example results unbiased. Furthermore, in line with Damodaran (2005), the possibility of quoting in the future moderates the liquidity premium, so, the restricted shares do not seem the most appropriate method.

Finally, Bajaj et al. (2001) adds that the great heterogeneity of the data implies an unrealistic overall discount and propose a cross section model throughout 88 private placements for the period 1990-1995. This discount for private placements, in which the dependent variable is calculated as the difference between the MARKET price previous to and after the IPO, is controlled by the following independent variables: the percentage of shares issued over total shares after issue, the Z-Score, originally devised by Altman (1968), the volatility of the issuing firm's returns and a dummy whether or not the issue is registered. He found an additional discount of $14.09 \%$ for unregistered shares and concludes that this is the appropriate discount due to lack of marketability.

III) Comparable acquisitions approach has been the technique most developed in recent years. Koeplin and Saphiro (2000) compares public versus private acquisition matching with each private acquisition of a public company similar in size, country, industry and year (84 acquisitions of private companies in the United States and 108 acquisitions outside the United States) for the period 1984-1998. The private company discount is measured as:

$$
1 \text { - (private company ratio/public company ratio). }
$$

They found in domestic transactions for Enterprise Value (EV)-EBITDA (earnings before interest, taxes, depreciation and amortization) an average discount of $28 \%$, for EV-EBIT (earnings before interest and taxes) 20\%, for EV-Book (net assets at book value) 18\%, and for EV-SALES value ratios negative and not statistically significant. In foreign firms $44 \%, 54 \%$, $35 \%, 43 \%$ respectively for each EV ratio, but only the first two are statistically significant. The authors thought these discounts could be explained in part by economic differences and also estimated cross-sectional regressions of the different multiples on size, growth, industry, and a dummy variable indicating the public or private condition. They concluded similar results in domestic deals, and in foreign transactions only for the EV-EBIT ratio, albeit the authors do not incorporate the results of the regression model in the article.

On the other hand, Kooli et al. (2003) criticizes in previous works the way of matching private with public enterprises one to one. He uses a portfolio of public companies transactions (based on year, industry and country) as the comparison metric. The private discount for sales, earnings and cash flow ratios were $17 \%, 34 \%$, and $20 \%$, respectively. Besides, he included a study, by a regression analysis, and he found that private discount, calculated 
from (1) varies due to a firm's characteristics (size and growth) and by industry classification. However, Block (2007) based on Koeplin's analysis, re-matched enterprises one to one from the 1999-2006 period introducing eight different industries (in 91 transactions), including financial institutions. He reported discounts of between $14.47 \%$ for EV-BOOK value and 24.49\% for EV-Revenue.

Officer (2007), basing his work on comparable acquisitions matching one enterprise with a portfolio on size, industry and year -according with previous studies of Kaplan and Ruback (1995)-. He found an average discount, but also demonstrated how these discounts vary with the need of the seller for liquidity, and the liquidity conditions of the debt and equity markets. The author notes important characteristics in the database: the great range of values for each multiple, the outliers' presence, and the lack of financial information in a great part of private transactions. In private transactions, prior to implementing control factors, multiples come out higher than public ones. These differences could be correlated with firms' economic characteristics, for example because unlisted targets are new and are high growth companies, so they would command higher EV ratios. After matching, he found an appropriate discount lies at about the 15-30\% range based on price-earnings, EV-EBITDA, and EV-SALES multiples; however, the PRICE-BOOK value multiple is not lower for stand-alone private firms. He concludes that parent firms sell subsidiaries at the point when their need for cash is the greatest. In fact, the discount is directly associated with parents' loan spreads and previous abnormal price returns.

In the same way, De Franco et al. (2008) proposes a cross section model to explain each ratio based on size and growth, as well as for the EV-SALES multiple in research and development and profit margin, controlled by sector and year. He includes a dummy variable representing public or private character to obtain the discount. However, he also estimates the private company discount implementing equation (1) from the media of database, using EV-EBITDA and EV-SALES multiples. Finally, considering the deterministic value of the ratio media of public enterprises as the implicit value for the previous proposed regression, he recalculates the value of the private enterprises, obtaining a range of $21 \%$ to $37 \%$ of the illiquidity discount. The period is 1995 to 2004 for 664 private and 2,225 public firms.

Nevertheless, he finds that the PRICE-BOOK value multiple is not lower for private firms, rather it is significantly higher. Quality information is the base of the discount explanation. Private firms, compared to public firms, tend to have more primitive accounting systems and, worse, internal controls that imply lower earnings quality.

Other studies, such as Cooney et al. (2009), developed a regression model between announcement returns on public acquirers and changes in the valuation of their private acquisitions (they compare the price of IPOs enterprises and their withdrawn IPO and found a positive relationship). This fact could explain in part prior private undervaluation and could be the consequence of behavioural biases in negotiation, and pricing effects associated with target valuation uncertainty. In fact, empirical analysis evidences that target valuation uncertainty is an important factor in returns on public acquirers. This discount would represent one other factor to separate from the $M D$ or even affect it.

Completing the above, Elnathan et al. (2010) explore experts' compliance in private versus public firm valuations. The sample consists of 147 company valuations (81 are public and 66 
are private) conducted by financial experts throughout the period 1991-2006 in the Israeli market. He found asymmetries in the prices of both enterprise groups across a regression model, but, in line with De Franco et al. (2008), he determined the discount directly as the difference between private and public valuations media of EV ratios and found a discount for the EV-EARNING ratio lower for private firms than for public firms (21\%). However, the medium value of the EV-BOOK ratio is higher. Lastly, they evaluated the influence of experts in the two ratios with a regression model in which the explanatory variable is the EV-ratio and the independent variables are: size, leverage, earning growth, ROE and a dummy variable representing the commissioner buyer or seller. He found inconclusive results regarding the existence of a discount in private firm valuations due to the fact that this discount could be the consequence of the experts' compliance with the interests of the commissioner of the valuation.

Finally, Paglia and Harjoto (2010) match 431 pairs of public-private enterprises based on a six-digit industry classification, year, and annual net sales. They found discounts of nearly $70 \%$ in some sectors of the economy. They calculated it for the two ratios: EV-SALES and EV-EBITDA. Further, using a multivariate regression analysis they examined the factors that influence the discount: larger EBITDA over sales involves a lower discount, positive profits also involves negative adjustment in discount, asset purchase has a lower risk and discount compared to stock purchase; status corporation " $\mathrm{C}$ " (higher levels of financial risk) involves largest discounts. Lastly, when the buyers of private companies are public companies the discount is lower by about $17 \%$ to $18 \%$.

To sum up the previous works in the comparison of public versus private acquisition, some authors try to isolate the Marketability discount $(M D)$ matching private versus public ones to one enterprise (Koeplin \& Saphiro, 2001; Block, 2007; Paglia \& Harjoto, 2010); while others, match private with a portfolio of enterprises created under the criteria of a peer group selection (Kooli et al., 2003; Officer, 2007). We find a consensus in the control factors to explain the differences between public-private prices: Industry, Size, Year and Country (Koeplin \& Saphiro, 2001; Kooli et al., 2003; Block, 2007; Officer, 2007) are the most used control factors to isolate $M D$.

Nevertheless, there is not a consensus in the criteria to explain the lack of Marketability $(M D)$. Kooli et al. (2003) uses Industry, Size and Growth, while Officer (2007) remarks on the parents' need for cash and loan spreads, and Paglia and Harjoto (2010) introduces EBITDA margin, dummy of positive profits, asset or stock purchase and status liability.

Finally, other authors search for the differences between public-privates enterprises' prices as a sum of different causes: De Franco et al. (2008) adds earnings quality, Cooney et al. (2009) the revision on the target valuations of the IPO with respect to the withdrawn, and Elnatham et al. (2010) the role of commissioners.

\subsection{The market ratio valuation framework}

In parallel to the illiquidity framework, the academic literature has evaluated multiple's behaviour on the choice of peer group and their ability to explain cross-sectional variations in stock prices. There is a consensus about the necessity to add economic-financial factors to 
industry and size selection factors (Alford, 1992; Kim \& Ritter, 1999; Liu et al., 2002; E. Lie \& H. J. Lie, 2002; Bhojraj \& Lee, 2002; Young \& Zeng, 2015).

Moreover, in line with Kaplan and Ruback (1995), Baker and Ruback (1999) and Bhojraj and Lee (2002), to understand the performance of multiples it is important to interpret them as an application of a growing perpetuity of the cash flow valuation model -DCF-CAPM model-. Therefore, the variables that affect a growing perpetuity of the cash flow valuation model are also going to affect the multiples. For example, in the case of the EBITDA multiple, the point of reference is the definition of free cash flow, FCF (cash generated by assets that a company can distribute among all the security holders and financial creditors), measured as earnings before interest and after taxes minus the necessity or variation in working capital $(W C)$ and capital expenditures (CAPEX). Equations (1) and (2) represent this concept:

$F C F=(E B I T D A-$ Depreciation $) x(1-t)+$ Depreciation - Variation of WC \& CAPEX.

If $\mathrm{t}($ tax rate $)=0$

$$
F C F=E B I T D A-\text { Variation of WC \& CAPEX. }
$$

Equation (3) represents the DCF-CAPM model, which defines enterprise value $(E V)$ as a function of FCF, the expected growth rate of it $(g r)$, and the weighted average cost of capital (WACC):

$$
E V=\frac{F C F(1+g r)}{W A C C-g r} .
$$

Substituting (2) in (3), the analytical expression of the multiple is obtained:

$$
\frac{E V}{E B I T D A}=\frac{1+g}{W A C C-g} \times\left(\frac{\text { Variation of } W C \& C A P E X}{E B I T D A}\right) .
$$

In this line, the following equation presents analytical expressions for EV-SALES:

$$
\frac{E V}{\text { SALES }}=\frac{1+g}{W A C C-g} \times\left(\frac{E B I T D A-\text { Variation of } W C \& C A P E X}{\text { SALES }}\right) .
$$

According to equations (4), (5), these multiples are a function of " $g$ ", the growth rate of $E B I T D A$, the "WACC" or return required by the company's financial structure, and the necessities to invest in asset structure (WC and CAPEX) between EBITDA or sales, depending on the ratio considered. In the case of the $E V$-SALES ratio, it also depends on the profit margin of EBITDA between sales. The same control factors that affect valuation ratios, could also affect the illiquidity discount (ID). Thereby, expression (6) defines the illiquidity discount as follows:

$$
I D=\frac{E V_{-} R A T I O_{P U B L I C}-E V_{-} R A T I O_{P R I V A T E}}{E V_{-} R A T I O_{\text {PUBLIC }}} .
$$




\subsection{Hypothesis}

Following (6) the illiquidity discount (ID), could be calculated as the sum of the percentages of change for each magnitude of (5). In fact, there is a consensus about the systematic differences in characteristics of the private versus public firms that are acquired. In this sense, private companies could tend to be smaller and exhibit higher earnings growth rates or margins, etc. For this reason, applying (6) we could find a negative illiquidity discount in any $E V$ ratio because private enterprises have a major growth rate or a profitability margin. However, $I D$ is not the marketability discount or $M D$, so to separate this, it is necessary: firstly, to identify the differences in economic characteristics between both groups of enterprises private and public. In previous woks, industry, size and year (Officer, 2007), also adding growth (Koeplin \& Saphiro, 2000; Kooli et al., 2003) or a combination between size and growth (De Franco et al., 2008), or even only industry (Block, 2007), are the control factors in the matching technique or in the choice of the peer group before applying equation (1). This work, to obtain the peer group, checks different possibilities to complete the map of control factors according to equations (4) and (5). So, the first hypothesis is:

H.I: to calculate MD from (1) industry and size is not enough, and also different economic and financial characteristics have to be applied:

H.I.I: market ratios and profitability and growth variables -profit margin and growth of EBITDA- are positively correlated.

H.I.II: as a consequence of the discount required by capital, the level of leverage and the standard deviation of the EBITDA have a negative relationship with market ratios. The standard deviation is also an indicator about quality information (De Franco et al., 2008).

Secondly, after reviewing the literature, ID in equation (6) has to be the result of different discount premiums not only derived from economic differences, so:

$$
I D=F(R E D, C D, P D, M D) .
$$

In equation (7) RED represents real economic differences between public and private enterprises, shown in $H I$, but other causes to explain the differences between public and private enterprises are: $C D$, the percentage of control in the acquisition (Damodaran, 2005; Officer, 2007) and $P D$, personal discounts, including the type of buyer (Cooney et al., 2009) based on different motivations and synergies in the purchase, as well as, for example the owners' need of liquidity -sellers' characteristics- (Officer, 2007). Only once with time delimited previous factors, could we determine the fair Marketability discount called $M D$.

This research focuses on the buyers' characteristics and negotiation capacity. So, the second hypothesis checks the following relationships:

H.II: the price of EV-ratios is positively correlated with:

H.II.I: the percentage of control in the acquisition.

H.II.II: the buyer synergies.

After delimiting previous control factors, the fair Marketability discount $(M D)$ could be approximated. So, our third hypothesis is:

H.III: a negative significant relationship exists between $E V$ ratios and private enterprises with reference to public enterprises. 
Finally, in line with the results of Bajaj et al. (2001), Kooli et al. (2003) and Paglia and Harjoto (2010), the investor's perceptions over control factors in public compared to private enterprises, could explain and originate different $M D s$.

So, $\boldsymbol{H} I V$ is: investors pay in the EV ratios each unit of the same variable of equation (7) differently, depending on whether the enterprise is public or private. Investor's perceptions about the problems derived from the lack of marketability create the MD. Our four sub-hypothesis are:

H.IV.I: investors pay differently for the size in each ratio for public versus private enterprises.

H.IV.II: investors pay more profitability variables, growth and margins, for public than for private enterprises.

H.IV.III: at the same time MD increases with risk variables, leverage and GSE.

H.IV.IV: the type of buyer and his negotiation capacity are decisive factors not only in price ratios, but also in the discount for marketability.

\section{Material and methods}

\subsection{Data collection}

The firms' data have been obtained from Zerphir, a merger and acquisition database with integrated detailed company information from Bureau Van Dijk, from the period 2006-2017. Initially, the initial sample included 4,339 firms. The observations with values missing from any of the variables have been removed and also the negative value multiples, because it is not possible to use them as a measuring tool. Moreover, the outliers corresponding to $5 \%$ of the lower and upper limits of the two ratios have been eliminated. Finally, the empirical test offered below includes 824 observations.

In line with Kooli et al. (2003) and Officer (2007), the matching technique one to one in a reduced number of data could involve errors, bias and an unrepresentative nature of the population. According to Bajaj et al. (2001) and De Franco (2008), the valuation methodology applied is a cross section model. Following Elnathan et al. (2010), with the purpose of homogenizing the data and allowing a non-linear relationship, each continuous variable has been transformed into its natural logarithm. The model identifies $M D$ as a dummy variable $(0,1)$ joining the rest of the control factors affecting the ratios. The regression also controls for cyclical behaviour by incorporating year dummies. Finally, to solve other problems derived from heteroscedasticity, the asymptotic variance of errors has been consistently estimated with the so-called robust standard errors (White, 1980).

\subsection{Variables and model}

The model introduces variables that capture Size, profitability, risk, control and the type of buyer. In this way, the marketability discount, $M D$, can be isolated checking, at the same time, the impact of the rest of the variables in each $E V$ ratio.

\section{Dependent variables}

The dependent variable EV-RATIO is a generic nomenclature referring indifferently to the EV-EBITDA and the EV-SALES. The EV-EBITDA multiple is calculated as the ratio between 
firm value, which is obtained by summing up market capitalization and financial liability at book value, and EBITDA. The EV-SALES multiple is the ratio obtained by dividing firms' value and the sales obtained for each company.

\section{Independent variables}

Firstly, expression 8 introduces the following independent economic variables to contrast hypothesis I:

Industry, the 17 industries based on the primary code of NACE, rev. 2.

Size, the enterprise's assets amount at book-value. This variable is a categorical dummy variable, building four group levels for each moment in time.

Table 2. Dimension and role of independent variables

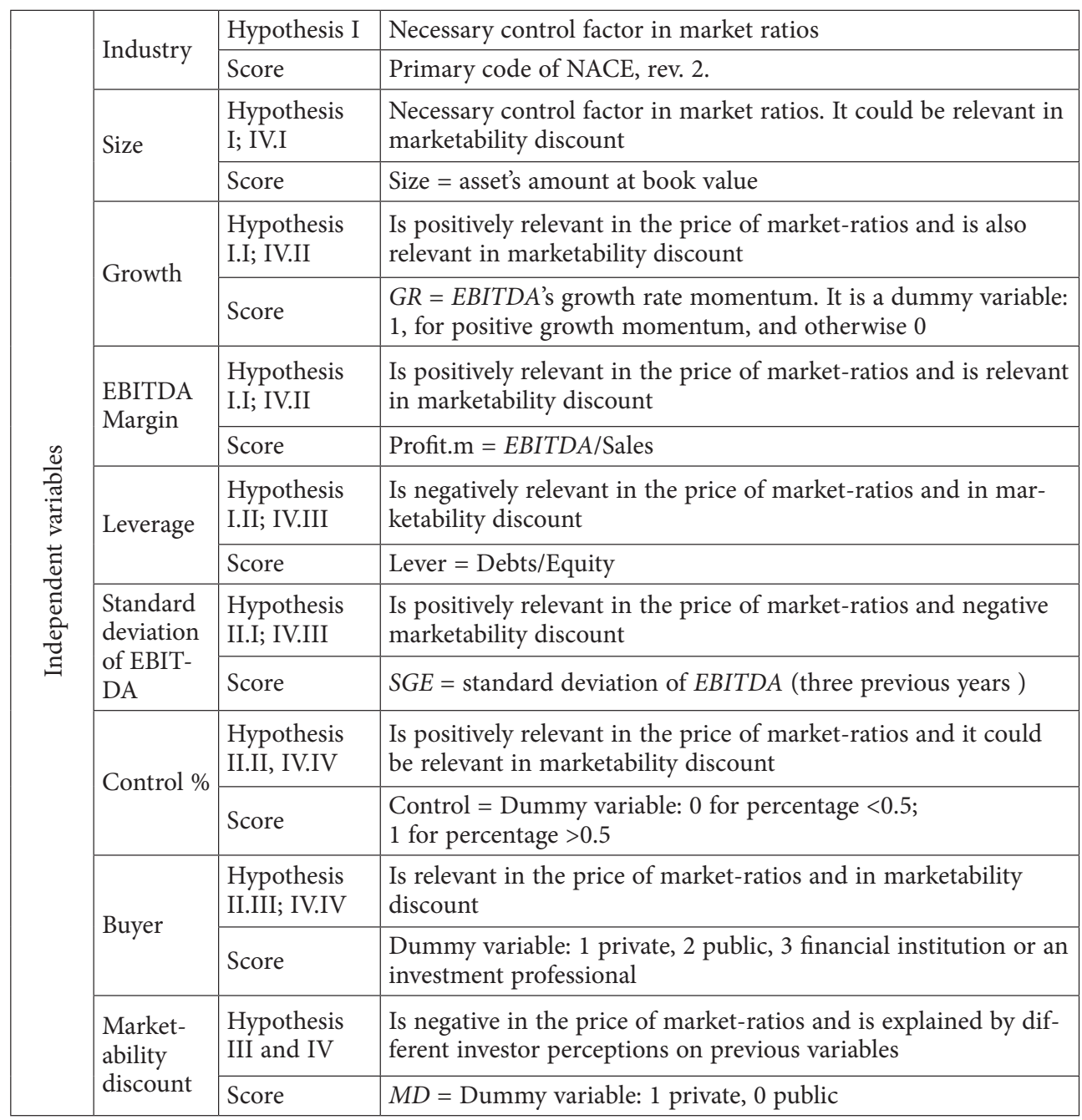


$\boldsymbol{G R}$ is the EBITDA's growth momentum of each company. It is a dummy variable: 1, if the comparison of EBITDA's growth with regard to the medium growth of the series of two previous years is positive, and otherwise 0 .

Lever is the leverage ratio (debts between equity) in continuing time at the year when the enterprise was sold.

SGE, the standard deviation of EBITDA of each company, calculated over three periods: the current and the two previous years.

Profit $_{\text {marg }}$ is the coefficient of EBITDA between sales.

Secondly, to contrast hypothesis II, we have introduced in (8) variables that capture the buyers' characteristics and their negotiation capacity, $C D$ and $P D$ in 7 , we have introduced Control, as the control percentage of the acquired enterprise: 0 if control is $<0.5$ and 1 otherwise. Finally, the variable Buyer represents the type of buyer in specification (8). The classification of the buyer type is: 1 , when the buyer of the enterprise is private, 2 , when it is a public enterprise and 3 when it is a financial institution or a professional investment such as Risk Capital or Family Office.

Thirdly, to contrast hypothesis III, expression 8 adds a dummy variable, $M D$, indicating if the enterprise sold is public, 1 , or private, 0 .

$$
\begin{aligned}
& E V \_ \text {Ratio }=\alpha+\beta_{1} \text { Year }_{t}+\beta_{2} \text { Industry }_{i}+\beta_{3} \text { Size }_{i}+\beta_{4} M D_{i}+\beta_{5} G R+\beta_{6} \text { Lever }+ \\
& \beta_{7} S G E+\beta_{8} \text { Control }+\beta_{9} \text { Buyer }+\varepsilon_{i} .
\end{aligned}
$$

Finally, to check the hypothesis and sub-hypothesis IV, expression 9 introduces the interaction between size, profitability, risk, including quality information, buyer and control with $M D$ in equation (9). Table 2 resumes variables and hypotheses.

$$
\begin{aligned}
& E V_{-} \text {Ratio }=\alpha+\beta_{1} \text { Year }_{t}+\beta_{2} \text { Industry }_{i}+\beta_{3} \text { Size }_{i}+\beta_{4} M D_{i}+\beta_{5} G R+\beta_{6} \text { Lever }+\beta_{7} S G E+ \\
& \beta_{8} \text { Control }+\beta_{9} \text { Buyer }++\beta_{10} M D \times \text { Size }_{i t}+\beta_{11} M D \times G R_{i t}+\beta_{12} M D \times \text { Lever }+ \\
& \beta_{13} M D \times S G E+\beta_{14} M D \times \text { Control }+\beta_{15} M D \times \text { Buyer }+\varepsilon_{i} .
\end{aligned}
$$

\section{Results}

\subsection{Descriptive summary}

Tables 3 to 6 present differential characteristics between listed and non-listed enterprises in independent variables. The magnitudes EBITDA, Sales and EV, as well as profit margin, leverage and Size are bigger for listed enterprises. The other independent variable, mean growth of EBITDA is positive for listed and negative in non-listed enterprises; the dichotomy variable GR is positive in 56\% and 52\% of listed and non-listed companies respectively. Regarding the dependent variable, the EV-EBITDA and EV-SALES mean value are bigger in listed companies.

Analyzing the type of control in Table $457.35 \%$ of non- listed companies present a percentage of acquisition equal or above $50 \%$, while in listed companies only $3.29 \%$ of acquisitions does so. The buyers' decisions are also very different (Table 5): financial institutions and professional buyers, along with listed enterprises, have bought more listed enterprises: 


\begin{tabular}{|c|c|c|c|c|c|c|c|c|c|c|c|c|c|c|c|}
\hline \multirow{5}{*}{ 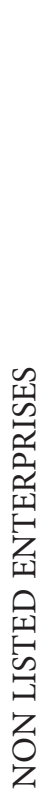 } & $\stackrel{\star 凶}{\Sigma}$ & $\begin{array}{l}\text { L } \\
\text { aे }\end{array}$ & $\begin{array}{l}\text { के } \\
\text { ம் }\end{array}$ & $\begin{array}{l}8 \\
0 \\
0 \\
0 \\
0 \\
0\end{array}$ & 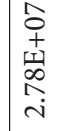 & 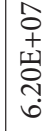 & $\begin{array}{l}\text { f } \\
\stackrel{0}{0} \\
\text { in } \\
\text { ñ }\end{array}$ & $\begin{array}{l}\text { 울 } \\
\text { m. } \\
\infty 0 \\
\infty \\
\infty\end{array}$ & $\begin{array}{l}\text { ô. } \\
\text { in }\end{array}$ & $\begin{array}{c}\infty \\
m \\
m\end{array}$ & 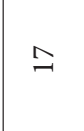 & $H$ & - & - & $N$ \\
\hline & $\stackrel{\Xi}{\Sigma}$ & $\stackrel{\sharp}{\sharp}$ & $\stackrel{m}{0}$ & $\wedge$ & $\stackrel{2}{a}$ & $\stackrel{\varrho}{0}$ & 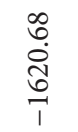 & $\neg$ & $\ddot{0}$ & $\overrightarrow{0}$ & $\neg$ & - & 0 & 0 & 0 \\
\hline & 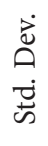 & $\begin{array}{l}\text { f̆ } \\
\text { ம. }\end{array}$ & $\stackrel{?}{\stackrel{9}{r}}$ & 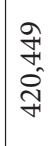 & $\begin{array}{l}\hat{0} \\
\infty \\
\hat{0} \\
0 \\
0 \\
\hat{N}\end{array}$ & 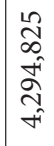 & $\begin{array}{l}\infty \\
0 \\
\tilde{N} \\
\end{array}$ & $\begin{array}{l}\frac{3}{4} \\
\hat{m} \\
\hat{b}\end{array}$ & $\begin{array}{l}\infty \\
\stackrel{\infty}{\sim} \\
i\end{array}$ & $\begin{array}{c}m \\
\tilde{\sigma} \\
\underline{n}\end{array}$ & $\underset{\sim}{\stackrel{\sim}{*}}$ & $\vec{\sigma}$ & in & in & $\bar{\sigma}$ \\
\hline & $\stackrel{\Xi}{\Xi ँ ~}^{\Xi}$ & 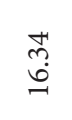 & $\stackrel{\Re}{\sigma}$ & $\begin{array}{l}0 \\
0 \\
0 \\
6\end{array}$ & $\begin{array}{c}\infty \\
\stackrel{\infty}{+} \\
\stackrel{m}{m} \\
m\end{array}$ & 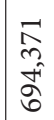 & $\begin{array}{l}\text { 우 } \\
\text { p. } \\
1\end{array}$ & 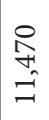 & స. & $\stackrel{\sim}{\check{m}}$ & $\hat{\Omega}$ & f & 帒 & กี & 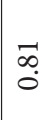 \\
\hline & $\tilde{0}$ & ஓ & ஓ & ஓ & ஓ & ஓ & ஓ & ஓ & ஓ & ঞ & ஓ & ஓ & ஓ & ஓ & ஓ \\
\hline \multirow{5}{*}{ 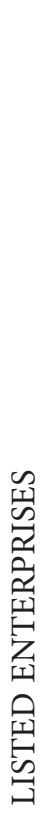 } & $\stackrel{\Perp 凶}{\Sigma}$ & 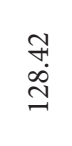 & 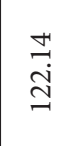 & $\begin{array}{l}8 \\
8 \\
8 \\
0 \\
0 \\
0\end{array}$ & 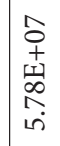 & 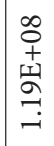 & 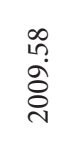 & $\begin{array}{l}\vec{\alpha} \\
\hat{\alpha} \\
\hat{+} \\
\infty \\
\infty\end{array}$ & $\stackrel{\infty}{\stackrel{\infty}{0}}$ & $\begin{array}{l}\infty \\
\infty \\
\infty \\
\infty \\
\infty\end{array}$ & 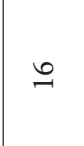 & $H$ & - & - & $N$ \\
\hline & $\Xi$ & $\bar{\sigma}$ & $\stackrel{20}{0}$ & $\stackrel{\infty}{\beth}$ & $\stackrel{2}{\infty}$ & $\begin{array}{l}n \\
0 \\
0 \\
0\end{array}$ & $\stackrel{\stackrel{2}{T}}{\underset{1}{\top}}$ & $\hat{\sigma}$ & O̦. & $\overrightarrow{0}$ & $N$ & - & 0 & 0 & 0 \\
\hline & $\begin{array}{l}\overrightarrow{\tilde{D}} \\
\dot{0} \\
\dot{\vec{D}}\end{array}$ & ஸ઼ & ڤે & $\begin{array}{l}\text { సิ } \\
\hat{\gamma} \\
\hat{\sigma} \\
-1\end{array}$ & 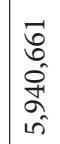 & $\begin{array}{l}8 \\
8 \\
8 \\
8 \\
0 \\
10\end{array}$ & $\begin{array}{l}\vec{b} \\
\stackrel{n}{=} \\
=\end{array}$ & 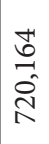 & $\bar{\sigma}$ & $\begin{array}{c}m \\
\stackrel{0}{a} \\
\alpha\end{array} \mid$ & $\stackrel{\text { ڤે }}{\text { ஸे }}$ & $\stackrel{n}{\stackrel{n}{0}}$ & $\stackrel{\infty}{\rightarrow}$ & $\begin{array}{l}\text { 우 } \\
0\end{array}$ & ô \\
\hline & $\stackrel{\text { चี }}{\sum_{\Sigma}}$ & $\stackrel{m}{\stackrel{2}{\beth}}$ & $\underset{\infty}{\infty}$ & $\begin{array}{l}0 \\
0 \\
0 \\
\hat{R} \\
1\end{array}$ & $\begin{array}{l}\stackrel{2}{N} \\
\hat{N} \\
\hat{N} \\
\hat{N}\end{array}$ & 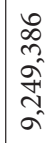 & $\begin{array}{l}\text { L } \\
\infty \\
\infty\end{array}$ & 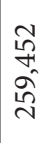 & in? & $\begin{array}{l}\vec{N} \\
\text { in }\end{array}$ & 占 & 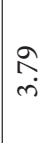 & $\stackrel{m}{0}$ & $\begin{array}{l}0 \\
1 \\
0\end{array}$ & ô \\
\hline & $\tilde{0}$ & mे & mे & mे & $\stackrel{\vec{m}}{m}$ & ले & mे & mे & $\stackrel{m}{m}$ & $\stackrel{m}{m}$ & $\stackrel{m}{m}$ & m & $\stackrel{+}{m}$ & $\stackrel{H}{m}$ & $\stackrel{m}{m}$ \\
\hline \multicolumn{2}{|c|}{$\begin{array}{l}\frac{\ddot{J}}{\vec{J}} \\
\stackrel{\vec{J}}{\overrightarrow{7}}\end{array}$} & 贫毁 & 贫至 & 岌 & 茎 & 齐 & 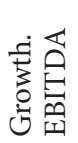 & 丽 & 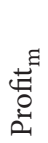 & 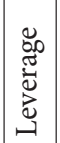 & 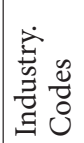 & $\stackrel{\tilde{N}}{\tilde{\omega}}$ & \begin{tabular}{l}
$\overrightarrow{0}$ \\
\multirow{0}{*}{} \\
0 \\
0
\end{tabular} & 怂 & 岕 \\
\hline
\end{tabular}


43.41\% and $16.17 \%$ respectively versus $34.29 \%$ and $13.27 \%$ (of not listed enterprises). Nevertheless, private enterprises preferred to invest in other not listed enterprises: $52.45 \%$ rather than $40.42 \%$ of listed enterprises.

Table 4. Frequencies of dichotomous variables

\begin{tabular}{|l|c|c|c|c|}
\hline \multirow{2}{*}{ Values } & \multicolumn{2}{|c|}{ LISTED } & \multicolumn{2}{c|}{ NON LISTED } \\
\cline { 2 - 5 } & Control (\%) & GR (\%) & Control (\%) & GR (\%) \\
\hline Yes & 11 & 3.29 & 281 & 57.35 \\
\hline No & 323 & 96.71 & 209 & 42.65 \\
\hline Total & 334 & 100 & 490 & 100 \\
\hline
\end{tabular}

Table 5. Frequencies of the type of buyer

\begin{tabular}{|l|c|c|}
\hline \multicolumn{1}{|c|}{ TYPE OF BUYER } & LISTED (\%) & NON LISTED (\%) \\
\hline Not listed enterprise & 40.42 & 52.45 \\
\hline Listed enterprise & 16.17 & 13.27 \\
\hline Financial institution & 43.41 & 34.29 \\
\hline Total & 100 & 100 \\
\hline
\end{tabular}

Table 6. Frequencies of ordinal variable size

\begin{tabular}{|c|c|c|}
\hline Size & LISTED (\%) & NON LISTED (\%) \\
\hline 1 & 0.3 & 16.33 \\
\hline 2 & 0.9 & 32.86 \\
\hline 3 & 17.96 & 38.57 \\
\hline 4 & 80.84 & 12.24 \\
\hline Total & 100 & 100 \\
\hline
\end{tabular}

The use of different variables of size, profitability, risk, control and buyer characteristics in the same equation also requires control of the correlations between them and testing for colinearity. Table 7 shows the absence of this problem. Moreover, the independent variables in the model have an individual medium FIV $<2.5$, which implies a tolerance index over 0.40. It is important also to remark that the Pearson correlation of $M D$ and the respective economic variables, except in profit margin and control, are negative: investors pay less in these variables for private enterprises compared to public enterprises.

\subsection{Regression analysis}

A regression model has been implemented to estimate expressions (8) and (9), incorporating robust errors. The model also controls for cyclical behaviour by incorporating year dummies. Table 8 presents the results of equation (8) for each multiple or EV-RATIO. There, important 
Table 7. Correlation matrix

\begin{tabular}{|l|c|c|c|c|c|c|c|c|c|c|c|}
\hline & $\begin{array}{c}E V / \\
E B I T- \\
D A\end{array}$ & $\begin{array}{c}E V / \\
\text { SALES }\end{array}$ & SGE & $\begin{array}{c}\text { Pro- } \\
\text { fit.m }\end{array}$ & $\begin{array}{c}\text { Lever- } \\
\text { age }\end{array}$ & $\begin{array}{c}\text { C.Sec- } \\
\text { tor }\end{array}$ & Size & $\begin{array}{c}\text { Con- } \\
\text { trol }\end{array}$ & GR & MD & $\begin{array}{c}\text { Buy- } \\
\text { er }\end{array}$ \\
\hline $\begin{array}{l}\text { EV/ } \\
\text { EBITDA }\end{array}$ & 1.00 & & & & & & & & & & \\
\hline EV/SALES & 0.17 & 1.00 & & & & & & & & & \\
\hline SGE & 0.02 & 0.10 & 1.00 & & & & & & & & \\
\hline Profit $m$ & -0.15 & 0.44 & 0.00 & 1.00 & & & & & & & \\
\hline Leverage & -0.05 & 0.05 & 0.13 & 0.03 & 1.00 & & & & & & \\
\hline Industry & 0.07 & -0.04 & -0.01 & 0.02 & 0.00 & 1.00 & & & & & \\
\hline Size & -0.08 & 0.19 & 0.23 & 0.02 & 0.04 & -0.08 & 1.00 & & & & \\
\hline Control & 0.10 & -0.20 & -0.04 & -0.19 & -0.08 & 0.08 & -0.01 & 1.00 & & & \\
\hline GR & 0.02 & 0.10 & 0.12 & 0.03 & 0.03 & -0.04 & 0.05 & -0.14 & 1.00 & & \\
\hline MD & -0.04 & -0.16 & -0.26 & 0.03 & -0.03 & 0.01 & -0.65 & 0.04 & -0.04 & 1.00 & \\
\hline Buyer & 0.09 & 0.06 & 0.06 & -0.03 & 0.03 & 0.04 & 0.05 & 0.06 & 0.09 & -0.12 & 1.00 \\
\hline
\end{tabular}

differences can be observed by Industry, meaning that each of them captures structural differences and capabilities to create value in the companies. Moreover, in relation to the economic cycle, results show a drop in the value of the two ratios in 2009 and 2011. For example, in the EV-EBITDA ratio, the fall is about 22\% over the intercept (year 2006), but in 2011 there is again a decline of $19 \%$, strongly recovered during the remaining period 2013-2017. This behaviour matches the trajectory of the last Spanish financial crisis and recovery. Therefore, in order to compare a company with a benchmark in Spain, it has to be controlled by Year and Industry.

Nevertheless, Profitability variables, GR and Profit ${ }_{m}$, also have a positive impact on the EV-EBITDA and EV-SALES ratios, while Risk variables, SGE and the leverage ratio, have a negative impact on the multiple values confirming hypothesis I and H.I.I, and H.I.II.

For this part Control is significant and represents a positive adjustment in the price of each ratio. The type of buyer also results in a decisive variable, confirming sub-hypothesis of H.II. In this sense, it is interesting to note that when the acquisition is made by a financial institution the price of both ratios increases.

Table 8. Estimation of equation (8): Cross section with robust errors

\begin{tabular}{|l|c|c|}
\hline & R.EV-EBITDA & R.EV-SALES \\
\hline Year & & -0.03 \\
\hline 2007 & -0.08 & 0.02 \\
\hline 2008 & 0.01 & $-0.34^{* *}$ \\
\hline 2009 & $-0.22^{\star *}$ & 0.14 \\
\hline
\end{tabular}


Continued Table 8

\begin{tabular}{|c|c|c|}
\hline & R.EV-EBITDA & R.EV-SALES \\
\hline 2011 & $-0.19^{\star \star}$ & $-0.34^{\star * *}$ \\
\hline 2012 & 0.07 & 0.10 \\
\hline 2013 & $0.43^{* * *}$ & $0.61^{\star * *}$ \\
\hline 2014 & $0.33^{* * *}$ & $0.79^{* * *}$ \\
\hline 2015 & $0.45^{\star * *}$ & $0.51^{\star * *}$ \\
\hline 2016 & $0.53^{\star * *}$ & $0.43^{* * *}$ \\
\hline 2017 & $0.81^{\star * \star}$ & $0.26^{\star * *}$ \\
\hline \multicolumn{3}{|l|}{ Industry } \\
\hline 2. Mining and quarrying & $-1.17^{\star * *}$ & $-1.19^{* * *}$ \\
\hline 3. Manufacturing industry & $-0.71^{\star * \star}$ & $-0.76^{\star * *}$ \\
\hline $\begin{array}{l}\text { 4. Supply of electricity, gas, steam } \\
\text { and air conditioning }\end{array}$ & -0.37 & -0.18 \\
\hline $\begin{array}{l}\text { 5. Water supply, sanitation activities, } \\
\text { waste management }\end{array}$ & $-0.80^{\star * *}$ & $-0.70^{\star * *}$ \\
\hline 6. Construction & $-0.45^{\star * *}$ & -0.17 \\
\hline $\begin{array}{l}\text { 7. Wholesale and retail trade; repair } \\
\text { of motor vehicles }\end{array}$ & $-0.96^{\star * *}$ & $-1.12^{\star * *}$ \\
\hline 8. Transport and storage & $-0.54^{* * *}$ & $-0.49^{* * *}$ \\
\hline 9. Hospitality & -0.42 & -0.24 \\
\hline 10. Information and communication & $-0.81^{\star \star \star}$ & $-0.77^{\star * *}$ \\
\hline 11. Real estate activities & 0.02 & 0.14 \\
\hline $\begin{array}{l}\text { 12. Professional, scientific and tech- } \\
\text { nical activities }\end{array}$ & $-0.92^{\star * *}$ & $-0.84^{\star * *}$ \\
\hline $\begin{array}{l}\text { 13. Administrative and support ser- } \\
\text { vice activities }\end{array}$ & $-0.77^{\star * *}$ & $-0.79^{\star * *}$ \\
\hline 14. Education & -0.61 & -0.61 \\
\hline $\begin{array}{l}\text { 15. Health activities and social ser- } \\
\text { vices }\end{array}$ & -0.48 & $-0.53^{* * *}$ \\
\hline $\begin{array}{l}\text { 16. Artistic, recreational and enter- } \\
\text { tainment activities }\end{array}$ & $-0.68^{\star * *}$ & $-0.56^{\star * *}$ \\
\hline 17. Other services & $-0.98^{\star * *}$ & $-0.79^{* * *}$ \\
\hline \multicolumn{3}{|l|}{ Size (Quartiles) } \\
\hline 2 & -0.13 & -0.08 \\
\hline 3 & 0.12 & 0.13 \\
\hline 4 & -0.05 & 0.02 \\
\hline GR & $0.10^{* * *}$ & 0.06 \\
\hline SGE & $-0.08^{\star * *}$ & $-0.03^{\star *}$ \\
\hline
\end{tabular}


End of Table 8

\begin{tabular}{|c|c|c|}
\hline & R.EV-EBITDA & R.EV-SALES \\
\hline Leverage & $-0.12^{\star * *}$ & $-0.16^{\star * *}$ \\
\hline Control & $0.04^{* *}$ & $0.04^{\star * *}$ \\
\hline \multicolumn{3}{|l|}{ Buyer. } \\
\hline 2. Public enterprise & -0.02 & -0.05 \\
\hline 3. Financial institution & $0.15^{* * *}$ & $0.13^{* * *}$ \\
\hline Profit $_{m}$ & & $0.65^{\star * *}$ \\
\hline$M D$ & $-0.38^{\star * \star}$ & $-0.27^{\star *}$ \\
\hline Intercept & $3.81^{\star * *}$ & $2.62^{\star * *}$ \\
\hline Prob $<=0.01^{* * *}$ & $\mathrm{~N}^{\circ}$ Observ $=824$ & No Observ $=824$ \\
\hline Prob $<=0.05^{\star \star}$ & $\mathrm{R} 2=0.27$ & $\mathrm{R} 2=0.70$ \\
\hline Prob $<=0.10^{*}$ & $\mathrm{~F}(37.786)=7.39$ & $F(38.785)=53.95$ \\
\hline
\end{tabular}

Furthermore, once separated the different control factors affecting the valuation ratios, $M D$ presents a negative and significant medium discount of $-38 \%$ and $-27 \%$, although the exact calculation of the variation is $\left(\mathrm{e}^{\mathrm{B}}-1\right),-32 \%$ and $-24 \%$ for EV-EBITDA as well for EVSALES, confirming hypothesis III.

To understand the behaviour of $M D$ in each ratio, Table 9 presents the results of the estimation of expression 9, which includes the interaction of Size, profitability and risk variables with $M D$, hypothesis $I V$. As a result of this inclusion the cross-effect with profitability and risk variables emerges, capturing the investor perception in reference to the lack of marketability for each variable in the model.

Table 9 shows that investors in the Spanish market pay different in non-listed enterprises for different sizes, risk, and also for profitability variables creating the marketability discount, $M D$, confirming hypothesis $\boldsymbol{I V}$. In this way, findings show different interactions between Size and $M D$ : there is a positive impact on size two, three and four in both ratios over the intercept, confirming $\boldsymbol{H}$. IV. I. In Table 9 the joint significance of every set of the Industry dummies, using a parametric test, resulted significant.

Table 9. Estimation of equation (9): Cross section with robust errors

\begin{tabular}{|c|c|c|}
\hline & R.EV-EBITDA & R.EV-SALES \\
\hline \multicolumn{3}{|l|}{ Size (Quartiles) } \\
\hline 2 & $-2.61^{\star \star \star}$ & $-2.28^{\star * *}$ \\
\hline 3 & $-1.18^{* * *}$ & $-0.98^{\star * *}$ \\
\hline 4 & $-1.73^{\star * *}$ & $-1.53^{\star * *}$ \\
\hline$G R$ & $0.13^{*}$ & 0.04 \\
\hline$S G E$ & -0.03 & 0.04 \\
\hline Leverage & -0.03 & $-0.12^{* * *}$ \\
\hline
\end{tabular}


End of Table 9

\begin{tabular}{|c|c|c|c|c|}
\hline & \multicolumn{2}{|c|}{ R.EV-EBITDA } & \multicolumn{2}{|c|}{ R.EV-SALES } \\
\hline Control & \multicolumn{2}{|c|}{$0.01^{*}$} & \multicolumn{2}{|c|}{$0.02^{\star *}$} \\
\hline \multicolumn{5}{|l|}{ Buyer } \\
\hline 2. Public enterprise & \multicolumn{2}{|c|}{-0.08} & \multicolumn{2}{|c|}{$-0.26^{\star \star \star}$} \\
\hline 3. Financial institution & \multicolumn{2}{|c|}{0.04} & \multicolumn{2}{|c|}{0.01} \\
\hline Profit $_{m}$ & & & \multicolumn{2}{|c|}{$0.76^{* *}$} \\
\hline$M D$ & \multicolumn{2}{|c|}{$-1.50^{\star * \star}$} & -1.3 & $5^{* * *}$ \\
\hline \multicolumn{5}{|l|}{ Size $\times M D$} \\
\hline 2 & \multicolumn{2}{|c|}{$2.58^{* * *}$} & \multicolumn{2}{|c|}{$2.33^{* *}$} \\
\hline 3 & \multicolumn{2}{|c|}{$1.44^{* * *}$} & \multicolumn{2}{|c|}{$1.32^{* * *}$} \\
\hline 4 & \multicolumn{2}{|c|}{$2.13^{\star * *}$} & \multicolumn{2}{|c|}{$2.15^{\star * *}$} \\
\hline$G R \times M D$ & \multicolumn{2}{|c|}{-0.02} & \multicolumn{2}{|c|}{0.04} \\
\hline$S G E \times M D$ & \multicolumn{2}{|c|}{$-0.09^{* * *}$} & \multicolumn{2}{|c|}{$-0.13^{\star * \star}$} \\
\hline Leverage $\times M D$ & \multicolumn{2}{|c|}{$-0.13^{\star * *}$} & \multicolumn{2}{|c|}{$-0.06^{* * *}$} \\
\hline Profit $_{m} \times M D$ & & & \multicolumn{2}{|c|}{$-0.19^{* * *}$} \\
\hline Control $\times M D$ & \multicolumn{2}{|c|}{0.01} & 0. & 2 \\
\hline \multicolumn{5}{|l|}{ Buyer } \\
\hline 2. Public enterprise $\times M D$ & \multicolumn{2}{|c|}{0.03} & \multicolumn{2}{|c|}{$0.27^{\star * \star}$} \\
\hline 3. Financial institution $\times M D$ & \multicolumn{2}{|c|}{$0.18^{\star * *}$} & \multicolumn{2}{|c|}{$0.18^{\star * *}$} \\
\hline Intercept & \multicolumn{2}{|c|}{$5.11^{\star * *}$} & \multicolumn{2}{|c|}{$3.93^{\star * *}$} \\
\hline Prob $<=0.01^{* * *}$ & \multicolumn{2}{|c|}{ No Observ $=824$} & No Obse & $\mathrm{rv}=824$ \\
\hline Prob $<=0.05^{\star \star}$ & $\mathrm{R} 2=$ & 0.30 & $\mathrm{R} 2=$ & 0.72 \\
\hline Prob $<=0.10^{*}$ & $\mathrm{~F}(45,7$ & 77) $=$. & $\mathrm{F}(47,7$ & $75)=$ \\
\hline & $\begin{array}{c}\text { Sector. } \\
\mathrm{F}(16.777)\end{array}$ & Year. F(11.777) & $\begin{array}{c}\text { Sector. } \\
\mathrm{F}(16.775)\end{array}$ & Year. F(11.775) \\
\hline & Prob $>F=0.00$ & Prob $>F=0.00$ & Prob $>F=0.00$ & Prob $>F=0.00$ \\
\hline
\end{tabular}

The interaction of $M D$ with Profit ${ }_{m}$ shows a negative adjustment of -0.19 in EV-SALES. In this form, for public enterprises, the coefficient of Profit ${ }_{m}$ is 0.76 , so, when this variable changes by $1 \%$, the public ratio increases by $0.76 \%$, while for private enterprises the increment is less, only $0.47 \%$ (0.76-0.19). Thereby, even if Profit ${ }_{m}$ represents an important value driver in both cases, in Spanish market investors pay less for profitability in private enterprises than in public ones.

Risk variables, SGE and Leverage, also have a negative adjustment on the original coefficient when the enterprise is private, -0.09 and -0.13 respectively in the EBITDA multiple, and -0.13 and -0.06 in EV-SALES. The sum of the interaction of risk variables with $M D$ and the original coefficient should be interpreted in the same form as previously. For example, in EV-EBITDA when SGE increases by $1 \%$ in public enterprises the ratio decreases by $0.03 \%$, whereas in private ones it does so by $0.12 \%$. This confirms a major reduction in private prices than in public ones for both ratios when the risk variables increase, confirming $H$. IV. II., and $\boldsymbol{H}$. IV. III. 
On the other hand, regarding the percentage of control in the acquisition, the interaction of Control and $M D$ is not significant, so control prime appears independent of marketability discount. However, regarding personal buyers' factors, financial institutions pay 0.18 more in private acquisitions than in public ones for both ratios. Furthermore, in EV-SALES when a public enterprise buys another private enterprise, the former pays 0.27 more, $\boldsymbol{H}$. IV. IV, while in EBITDA ratio this factor does not present any significant interaction.

Obviously, the concrete measure of $M D$ changes strongly depending on the independent variables, so, based on this methodology, the elaboration of practical tables of discounts based on level variables would be very interesting for practitioners. For example, in the SALES ratio, regarding only the level variables Size and buyer, considering Industry, code 1 (Agriculture, forestry and fishing) and Size 1, both in the intercept, the following expression can approximate the impact of MD \& Size: $\left(\mathrm{e}^{(-1.35+3.93)}-\mathrm{e}^{(3.93)}\right) / \mathrm{e}^{(3.93)}$, obtaining a higher discount of $-75 \%$. In this form, the joint result for Size 4 and the interaction with $M D-\left(\mathrm{e}^{(-1.35+3.93-1.53+2.15)}-\mathrm{e}^{(3.93)}\right) / \mathrm{e}^{(3.93)}$ - origins a lower discount of $-52 \%$. Moreover, if the buyer is a financial institution or a professional buyer, the Marketability prime falls to $-42 \%$. A similar analysis could be done for the rest of the continuous variables transformed in level variables.

\section{Discussion}

Merger and acquisitions of private enterprises represent an important way of largest enterprises' value creation (Schweiger \& Very, 2003) and private equity plays an important role in the financial growth cycle of small firms. Nevertheless, there is evidence about the lack of objectivity from analysts' recommendations in equity valuation (Kolasinski \& Kothari, 2008). Furthermore, wrong equity investment decisions have been evidenced in the last financial crisis, damaging the future of many firms and impairing their shareholders' interest, especially in the financial sector. Our results are very important to determine the fair marketability discount and a correct equity value of private deals.

There is a lack of consensus about the variables of the peer group in the illiquidity discount literature compared to a more developed market multiples' theoretical framework. For example, in a matching technique, Koeplin et al. (2000) take Industry, Size, Growth and Year; Kooli et al. (2003) and Officer (2007) Industry and Size; Block (2007) added Country and Paglia and Harjoto (2010) based the matching selection on Industry, Year and Net Sales. Something similar happens with authors that used a regression model, such as De Franco et al. (2008), based on Size and Growth.

Therefore, only Elnathan et al. (2010) introduced a more complete map of control variables: Size, Leverage, Earning Growth, ROE and a dummy variable about the commissioner buyer or seller. However, the last one omitted other important structural variables such as Industry. Moreover, he does not explain the marketability discount, but assesses the role of experts. Obviously if the peer group is not selected including all the variables affecting the ratios' prices, the results of mean $M D$ could be biased because the impact of each variable uncontrolled could be included in the assessed discount. 
This study makes a similar criticism in the explanation of the illiquidity discount (see Table 1). Only Bajaj et al. (2001) checked the influence of a wide portfolio of variables in the discount, albeit for private placement methodology. Paglia and Harjoto (2010) did so in a matching technique, but based it on an incomplete previous selection of the peer group.

This research contributes to calls from literature for a more integrated discussion of the marketability discount, MD. In line with Baker and Ruback (1999) and Bhojraj and Lee (2002) this model attempts to delimit the role of each variable in the valuation ratios following equations (4) and (5). Moreover, the analysis also added the percentage of control in the acquisition (Damodaran, 2005; Officer, 2007) and personal discounts, including the type of buyer (Cooney et al., 2009), incorporating a new division of buyers: financial and professional buyers, as well as private or public buyers. Following the equation (7), the findings suggest that:

First, in line with Bhojraj and Lee (2002) or Young and Zeng (2015), Industry and Size are not enough to explain the valuation ratios. Profitability variables (GR and Profit $_{m}$ ) have a positive impact on valuation ratios while risk variables, $S G E$ and Leverage, have a negative impact. On the other hand, Control has a positive impact on the ratio valuation and, finally, the type of buyer emerges as a relevant factor in the Spanish market. Financial institutions represent a positive adjustment (hypothesis II), in accordance with Koeplin et al. (2000) and Bajaj et al. (2001), because they provide some sort of service to the firm. This fact is implicit in the enterprises' price. Second, $M D$ has a negative impact on each ratio confirming its existence in the Spanish market (hypothesis III).

Thirdly, despite the likely bias in previous papers, due to the lack of previous delimitation of all necessary control factors, our results present different partial agreements with them. In line with Kooli et al. (2003) MD is strongly influenced by Size; but according to Paglia and Harjoto (2010) other risk and profitability variables also influence it. In fact, the interactions of $M D$ capture investors' perceptions towards illiquidity, and imply that investors pay less in private enterprises for different risks: Leverage and SGE, this last factor also in accordance with earnings quality theory (De Franco et al., 2008). Furthermore, in EV-SALES investors also pay less in private enterprises for profitability (Profit ${ }_{m}$ ) creating the Marketability discount, MD (hypothesis IV, IV I, IV II and IV III).

Moreover, the model also assesses the final impact of each variable on private/public ratio. For example, since the addition of the coefficient of the interaction of Profit $t_{m}$ with $M D$ plus the individual coefficient of Profit $t_{m}$ is positive an increment in private ratio is carried out. Therefore, in line with Paglia and Harjoto (2010), if profitability variables rise in a private enterprise respect its public peer group there is a final reduction in the global illiquidity discount, $I D$, following equation (7).

Fourthly, according to Cooney et al. (2009) or Paglia and Harjoto (2010) other buyer motivations, such as the type of buyer, have to be considered when explaining $M D$. Unlike previous authors in EV-SALES, when the buyer is a public enterprise, as well as when the buyer is a financial institution or a professional investor, the results present an overvaluation on $M D$, confirming our sub-hypothesis IV IV. 


\section{Conclusions}

This article presents a more integrated explanation about the illiquidity discount for comparable acquisitions approach methodology based on a recompilation of different theories from previous authors. The model applies a broader variety of control factors in ratios, especially the profitability and risk variables, as well as the traditional Industry, Size, Year and Country, alongside other personal motivations such as Control and the Type of Buyer. In this form the results highlights the importance of delimit $M D$ from other control factors, checking, in the same equation, the performance of each variable and the existence of $M D$.

This different algorithm to understand the illiquidity discount discovers important interactions of each control factor with $M D$ capturing investors' perceptions in respect to the illiquidity. In addition, investors pay less in private enterprises for risk, but also for profitability variables creating $M D$. Finally, other buyer motivations have to be taken into account: while Control appears irrelevant in its interaction, the type of buyer also has to be considered along with the other variables when explaining $M D$. As the discount varies considerably by variables, a practical result of this proposal could be the elaboration of tables for practitioners transforming some of the continuous variables by levels. These results, based on Industry and Size, suggest that the illiquidity discount $M D$ is strongly reduced when an enterprise's size increases.

This research covers a long period of time (11 years) representing, for the first time, clear evidence for analysts and regulators on the necessity to apply a marketability discount in Spanish private equity valuations, calculated with similar rules. The use of a standard and fair marketability discount would avoid erroneous equity valuation conclusions, giving accuracy to the investment decisions.

Even though this article provides a comprehensive method to identify the illiquidity discount, this study limitation is the absence of other negotiation elements, such as sellers' conditions, that can be introduced in future research. Another limitation is the geographical area, focused on the Spanish market. Future research could be the application of the model in other geographical areas and/or a more exhaustive analysis of the marketability discount depending on the different economic cycles. Finally, it would be important to analyze, in the years after an acquisition, the consequences in the purchasers' financial statements on applying a correct versus an incorrect illiquidity prime.

\section{Author contributions}

The present work has been designed, conceived and coordinated by Ángel Rodríguez López and Gracia Rubio Martín, who in turn have participated in the design of the research, the collection and analysis of the data, the interpretation of the results, the organization of the content and the wording. The two authors have also participated in the critical review of the work until reaching its final version.

\section{Funding}

No financing. 


\section{Disclosure statement}

There are no conflicts of interest.

\section{References}

Alford, A. W. (1992). The effect of the set of comparable firms on the accuracy of the price-earnings valuation method. Journal of Accounting Research, 30, 94-108. https://doi.org/10.2307/2491093

Altman, E. I. (1968). Financial ratios, discriminant analysis and the prediction of corporate bankruptcy. The Journal of Finance, 23(4), 589-609. https://doi.org/10.1111/j.1540-6261.1968.tb00843.x

Bajaj, M., Denis, D. J., Ferris, S. P., \& Sarin, A. (2001). Firm value and marketability discounts. Journal of Corporation Law, 27, 89-115. https://doi.org/10.2139/ssrn.262198

Baker, M., \& Ruback, R. S. (1999). Estimating industry multiples (Working Paper). Harvard University, Cambridge, MA. Retrieved from https://www.hbs.edu/faculty/Pages/item.aspx?num=1435

Block, S. (2007). The liquidity discount in valuing privately owned companies. Journal of Applied Finance, 17(2), 1-33.

Bhojraj, S., \& Lee, C. (2002). Who is my peer? A valuation-based approach to the selection of comparable firms. Journal of Accounting Research, 40(2), 407-439. https://doi.org/10.1111/1475-679X.00054

Celli, M. (2017). Minority discount for reduced powers in negotiations of non-listed minority holdings: evidence from European countries. International Journal of Business and Management, 12(4), 1-23. https://doi.org/10.5539/ijbm.v12n4p23

Cooney, J. W., Moeller, T., \& Stegemoller, M. (2009). The underpricing of private targets. Journal of Financial Economics, 93(1), 51-66. https://doi.org/10.1016/j.jineco.2008.08.001

Covrig, V., \& McConaughy, D. L. (2015). Public versus private market participants and the prices paid for private companies. Journal of Business Valuation and Economic Loss Analysis, 10(1), 77-97. https://doi.org/10.1515/jbvela-2014-0005

Damodaran, A. (2005). Marketability and value: measuring the illiquidity discount. SSRN Electronic Journal, 60. http://doi.org/10.2139/ssrn.841484

De Franco, G., Gavious, I., Jin, J., \& Richardson, G. D. (2008). The private company discount and earnings quality (Working Paper). University of Toronto. Retrieved from https://www.///C:/Users/Usuario/Downloads/The_Private_Company_Discount_and_Earnings_Quality\%20(2).pdf

Dong, J., Jiao, D., \& Sun, X. (2017). Acquisition discount and valuation effect of private M\&As in China. Journal of Systems Science and Complexity, 30(6), 1364-1381. https://doi.org/10.1007/s11424-017-5274-x

Emory, J. D. (1997). The value of marketability as illustrated in initial public offerings of common stock (eighth in a series) November 1995 through April 1997. Business Valuation Review, 16(3), 123-131. https://doi.org/10.5791/0882-2875-16.3.123

Elnathan, D., Gavious, I., \& Hauser, S. (2010). An analysis of private versus public firm valuations and the contribution of financial experts. The International Journal of Accounting, 45(4), 387-412. https://doi.org/10.1016/j.intacc.2010.09.001

Ferraro, O. (2017). Business valuation: premiums and discounts in international professional practice. In M. Bilgin, H. Danis, E. Demir, \& U. Can (Eds.), Financial environment and business development. Eurasian studies in business and economics (Vol. 4). Cham: Springer. https://doi.org/10.1007/978-3-319-39919-5

Garland, P. J., \& Reilly, A. S. (2004). Update on the Willamette Management Associates pre-IPO discount for lack of marketability study for the period 1998 through 2002. Insights (Willamette Management Associates), 38-44. 
Grbenic, S. O. (2017). Estimating the discount for lack of liquidity in valuing privately held businesses using trading frictions of stocks in small markets: an econometric model approach. The Business \& Management Review, 9(1), 1-8.

Gupta, V. (2018). Predicting accuracy of valuation multiples using value drivers: evidence from Indian listed firms. Theoretical Economics Letters, 8(5), 1-18. https://doi.org/10.4236/tel.2018.85052

Hertzel, M., \& Smith, R. L. (1993). Market discounts and shareholder gains for placing equity privately. The Journal of Finance, 48(2), 459-485. https://doi.org/10.1111/j.1540-6261.1993.tb04723.x

Kaplan, S. N., \& Ruback, R. S. (1995). The valuation of cash flow forecasts: An empirical analysis. The Journal of Finance, 50(4), 1059-1093. https://doi.org/10.1111/j.1540-6261.1995.tb04050.x

Kim, M., \& Ritter, J. R. (1999). Valuing IPOs. Journal of Financial Economics, 53(3), 409-437. https://doi.org/10.1016/S0304-405X(99)00027-6

Kolasinski, A. C., \& Kothari, S. P. (2008). Investment banking and analyst objectivity: Evidence from analysts affiliated with mergers and acquisitions advisors. Journal of Financial and Quantitative Analysis, 43(4), 817-842. https://doi.org/ 10.1017/S0022109000014368

Koeplin, J., Sarin, A., \& Shapiro, A. C. (2000). The private company discount. Journal of Applied Corporate Finance, 12(4), 94-101. https://doi.org/10.1111/j.1745-6622.2000.tb00022.x

Kooli, M., Kortas, M., \& L'her, J. F. (2003). A new examination of the private company discount: The acquisition approach. The Journal of Private Equity, 6(3), 48-55.

Lie, E., \& Lie, H. J. (2002). Multiples used to estimate corporate value. Financial Analysts Journal, 58(2), 44-54. https://doi.org/10.2469/faj.v58.n2.2522

Liu, J., Nissim, D., \& Thomas, J. (2002). Equity valuation using multiples. Journal of Accounting Research, 40(1), 135-172. https://doi.org/10.1111/1475-679X.00042

López, Á. R., Antón, A. J. M., \& Cerviño, E. F. (2011). The impact of financial crisis on profitability, asset turnover and state aid in SMEs. African Journal of Business Management, 5(33), 12.749-12.753. https://doi.org/10.5897/AJBM11.484

Officer, M. S. (2007). The price of corporate liquidity: Acquisition discounts for unlisted targets. Journal of Financial Economics, 83(3), 571-598. https://doi.org/10.1016/j.jfineco.2006.01.004

Paglia, J. K., \& Harjoto, M. (2010). The discount for lack of marketability in privately owned companies: a multiples approach. Journal of Business Valuation and Economic Loss Analysis, 5(1). https://doi.org/10.2202/1932-9156.1089

Pratt, S. P. (2009). Business valuation discounts and premiums. New Jersey: John Wiley \& Sons.

Rubio Martín, G. (2019). European valuation multiples: the investors' sentiment about size. Spanish Journal of Economics and Finance, 42, 173-188. https://doi.org/10.32826/cude.v42i119.86

Schweiger, D. M., \& Very, P. (2003). Creating value through merger and acquisition integration. In Advances in mergers and acquisitions (pp. 1-26). Emerald Group Publishing Limited. https://doi.org/10.1016/S1479-361X\%2803\%2902002-7

Serra, R. G., \& Fávero, L. P. L. (2017). Multiples' valuation: the selection of cross-border comparable firms. Emerging Markets Finance and Trade, 54(9), 1.973-1.992. https://doi.org/10.1080/1540496X.2017.1336084

Silber, W. L. (1991). Discounts on restricted stock: The impact of illiquidity on stock prices. Financial Analysts Journal, 47(4), 60-64. https://doi.org/10.2469/faj.v47.n4.60

White, H. (1980). A heteroskedasticity-consistent covariance matrix estimator and a direct test for heteroskedasticity. Econometrica: Journal of the Econometric Society, 48(4), 817-838. https://doi.org/10.2307/1912934

Wruck, K. H. (1989). Equity ownership concentration and firm value: Evidence from private equity financings. Journal of Financial Economics, 23(1), 3-28. https://doi.org/10.1016/0304-405X(89)90003-2

Young, S., \& Zeng, Y. (2015). Accounting comparability and the accuracy of peer-based valuation models. The Accounting Review, 90(6), 2571-2601. https://doi.org/10.2308/accr-51053 